\title{
From Saprotrophic to Clear Water Status: the Restoration Path of a Degraded Urban Lake
}

\author{
Jolanta Grochowska (i) - Renata Augustyniak • \\ Michal Lopata • Katarzyna Parszuto • \\ Renata Tandyrak • Anna Plachta
}

Received: 29 October 2018 / Accepted: 7 March 2019/Published online: 4 April 2019

(C) The Author(s) 2019

\begin{abstract}
The study was conducted on Długie Lake in Olsztyn, which for 20 years since the mid-1950s served as a domestic and storm wastewater receiver, which led to its complete degradation. The discontinuation of wastewater inflow in 1976 caused a change in the trophic state from saprotrophic to hypertrophic. Evident improvement of water quality was possible only after the implementation of proper restoration techniques. Długie Lake was subjected to artificial aeration with thermal destratification (1987-2000). After all opportunities to improve water quality in the lake by artificial aeration (low phosphorus sorption capacity of sediment) had been exhausted, it was decided that a phosphorus inactivation method using the coagulant PAX 18 be used (2001-2003). Before restoration, the nutrient concentration in the near-bottom water layer of Długie Lake was very high at $22.9 \mathrm{mg} \mathrm{TN} \mathrm{L}^{-1}$ and $3.50 \mathrm{mg} \mathrm{TP} \mathrm{L}^{-1}$. The average amount of chlorophyll a was ca. $200 \mu \mathrm{g} \mathrm{L}^{-1}$, and the Secchi disc visibility did not exceed $1 \mathrm{~m}$. In 2017, 14 years after termination of the lake restoration process, the total phosphorus concentration at the bottom was $0.21 \mathrm{mg} \mathrm{P} \mathrm{L}^{-1}$ on average, and the total nitrogen was $1.5 \mathrm{mg} \mathrm{N} \mathrm{L}^{-1}$. The mean transparency of the water oscillated around approximately $5 \mathrm{~m}$, and the amount of chlorophyll a was $1.86 \mu \mathrm{g} \mathrm{L}^{-1}$. Studies
\end{abstract}

J. Grochowska $(\bowtie) \cdot$ R. Augustyniak $\cdot$ M. Łopata

K. Parszuto $\cdot$ R. Tandyrak $\cdot$ A. Płachta

Department of Water Protection Engineering, Faculty of Environmental Sciences, University of Warmia and Mazury in

Olsztyn, Prawocheńskiego St. 1, 10-720 Olsztyn, Poland

e-mail: jgroch@uwm.edu.pl have shown that the most important step in reclamation is to prevent pollutants from entering the lake to the maximum extent possible and to use a combination of several reclamation methods as a matter of good practice. Stable environmental conditions have developed in the lake, and the values of chlorophyll a and the Secchi disk visibility indicate that the lake has reached a mesotrophic state.

Keywords Urban lake · Nutrients · Saprotrophic state · Chlorophyll a · Visibility

\section{Introduction}

One negative aspect of the urbanization, industrial and agricultural development, which occurred after World War II in Poland and throughout the world, especially in the mid-1950s, was the transformation of urban water bodies into wastewater receivers. The response to the inflow of excessive loads of mineral and organic components with sewage consists of accelerated eutrophication and even extreme degradation (Jorgensen 2001; Carpenter 2008; Fraterrigo and Downing 2008; Istvánovics 2009; Wang et al. 2012). Symptoms of degradation are especially visible as algal blooms, deteriorated water transparency, deoxygenation of water, or the occurrence of unwanted decomposition products such as ammonium and hydrogen sulfide near the lake bottom (Grochowska and Tandyrak 2007). Lakes situated within town limits may even pose an epidemiological threat by turning into pools of pathogenic bacteria, 
mainly Salmonella spp., which can invade the gastrointestinal tract (Colford et al. 2007), but also Aeromonas spp. and Legionella spp. (Inoue et al. 2015; Miyagi et al. 2016).

In such cases, protective measures are necessary. The first and foremost step is to cut off the flow of sewage into the lake and redirect it beyond the catchment area. In addition, leaky septic tanks and other uncontrolled sources of discharge of pollutants should be identified and eliminated. If lakes are surrounded by agricultural areas, it may be necessary to change the land use practices in the catchment area and reduce the amount of arable land in favor of grassland (Grochowska et al. 2011, 2014).

Very often degraded lakes do not respond to the reduction of external pollutants. This is due to the phenomenon of internal nutrient loading in the near-bottom water. Bottom sediments in anoxic conditions become a theoretically inexhaustible source of nutrients. In this case, it is necessary to carry out recultivation treatments (Brzozowska and Gawrońska 2005).

The rapid acceleration of the eutrophication process, which has been linked to human activities, has forced us to seek effective methods that inhibit this process or reverse its adverse consequences. To improve the quality of lake water in Poland and around the world, various recultivation treatments (technical, biological) have been developed that cause permanent nutrient immobilization in the sediments or the removal of excess nutrients outside of the lake ecosystem (Klapper 2003; Jeppesen et al. 2007; Sewell et al. 2016).

The aim of this publication is to present a case of an urban lake to demonstrate how easily a lake ecosystem can be destroyed and, above all, how difficult it is to restore a lake to its previous state. The recultivation of lakes, especially a completely degraded lake, is extremely difficult and requires knowledge of the complex processes that take place in the lake ecosystem, the right choice of recultivation methods and a consistent, often long-term study of their effectiveness. The costs are usually very high, often exceeding by a manifold amount the expenditure to be borne to prevent the degradation of a lake (Dunalska et al. 2015; Dunalska and Wiśniewski 2016). There are very few lakes around the world for which the monitoring of changes in environmental conditions caused by various factors (sewage inflow, protection, and recultivation) has been carried out over such a long period, 45 years, as in the case of the lake we shall discuss.

\section{Materials and Methods}

\subsection{Description of Study Area}

The object of the study is Długie Lake, a postglacial lake situated in the western part of the city of Olsztyn, in northeastern Poland. The lake's surface area is 26.8 ha. The lake has an elongated shape. The lake bowl is divided into three parts: a shallow $(3 \mathrm{~m})$ and small (2.3 ha) southern bay, the deepest $(17.3 \mathrm{~m}$ ) and largest (13.4 ha) middle section, and the northern section with a maximum depth of $5 \mathrm{~m}$ and a surface area of 11.1 ha (Fig. 1, Table 1). The lake bowl volume is $1,415,000 \mathrm{~m}^{3}$. It has no natural surface outflows and inflows. There is a small peat bog named Mszar located nearby in the direct catchment area of the lake, but these two water bodies do not directly influence each other. In the second half of the last century (1956-1976), this lake received raw domestic and storm wastewater $\left(350-400 \mathrm{~m}^{3}\right.$ day $\left.^{-1}\right)$, which led to the extreme degradation of this water body and its transformation to a saprotrophic lake type. The inflow of domestic sewage was limited in 1973 and finally discontinued in 1976. The cessation of sewage discharge into the lake caused the saprotrophic state to transform into a hypertrophic state. Further improvement of the environmental conditions in the lake was possible only after the implementation of an appropriate restoration method. In 2015, the inflow of rainwater to the lake, which has no natural tributaries or surface outflows, was also cut off. Currently, the lake is fed only with surface runoff from a small 115.4 ha catchment, atmospheric precipitation, and underground sources.

\subsection{Description of Restoration Methods}

The first method used for the restoration of Długie Lake was artificial circulation. This procedure was carried out over 10 years and consisted of two stages: during the first stage (in 1987, 1988, 1989, and 1990), three "minifloc" type aerators were used (Ø $1 \mathrm{~m}$, length $5 \mathrm{~m}, 10 \mathrm{~m}$, and $15 \mathrm{~m}$ ), localized in the central, deepest part of the lake (with $150 \mathrm{~m}$ intervals), and coupled with a compressor with an approximate capacity of $150 \mathrm{~m}^{3} \mathrm{~h}^{-1}$; during the second stage (in 1991, 1992, 1993, 1994, 1995, 1997, 1998, and 2000), two compressors (working alternately), with a capacity of ca. $80 \mathrm{~m}^{3} \mathrm{~h}^{-1}$, were used together with two "mini-floc" aerators $(\varnothing 1 \mathrm{~m}$, 


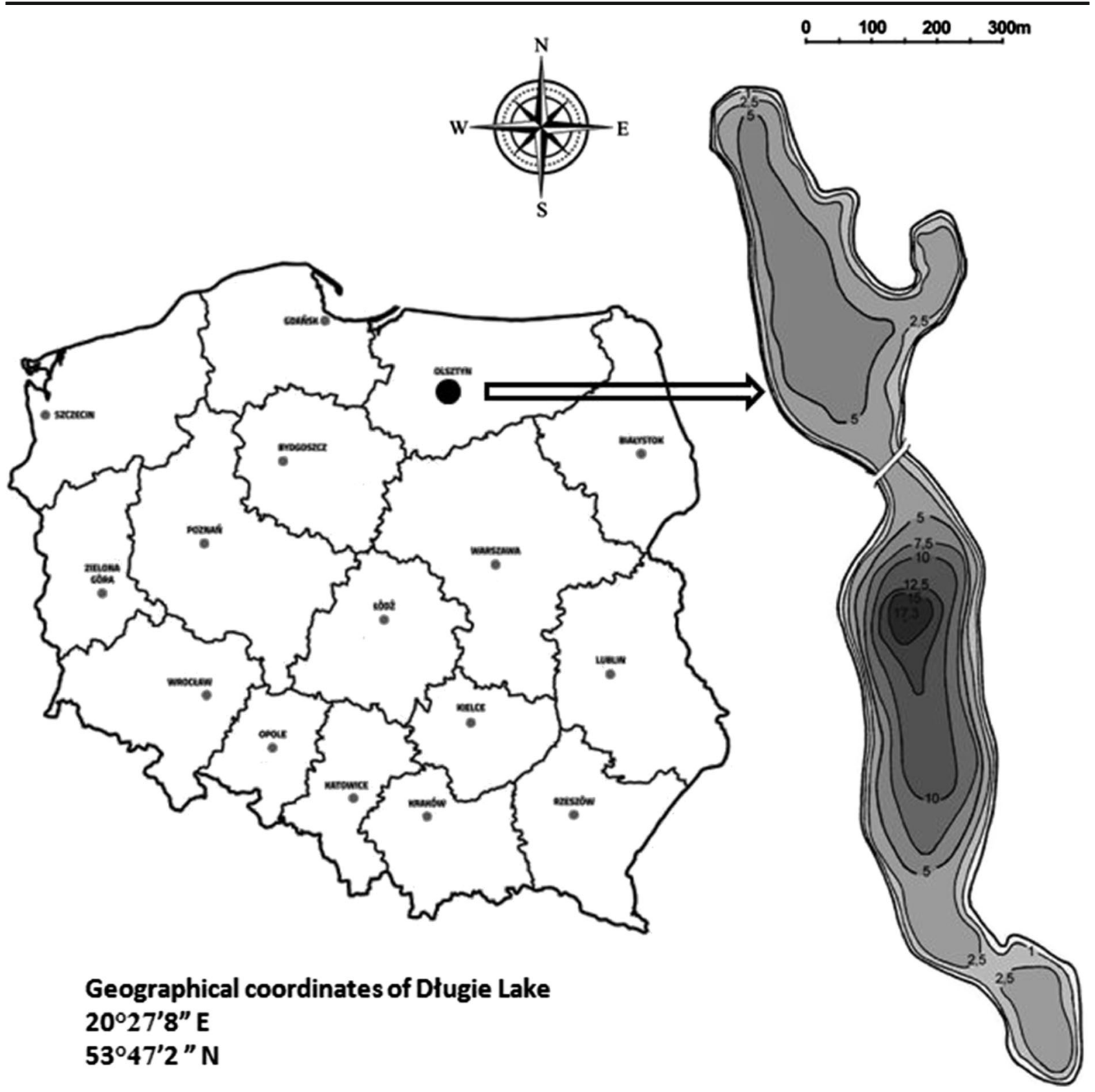

Fig. 1 Location of the research site

length $5 \mathrm{~m}$ and $10 \mathrm{~m}$ ), localized in the deepest and in the northern parts of the lake (the distance between them was $360 \mathrm{~m}$ ).

The failure of the original system to completely mix the water column was the main reason for changing the aeration system elements (such as the compressor type, localization of aerators, and the type of pipes supplying compressed air into aerators) (Grochowska and Gawrońska 2004). The aeration was conducted to the point that further improvement of the water quality in the lake by artificial circulation was no longer possible (due to the depletion of $\mathrm{Fe}$ and $\mathrm{Mn}$ in the lake water and the lack of possibility of further P precipitation). It was decided that another method of restoration, i.e., phosphorus inactivation, be used. Subsequently, phosphorus inactivation with a new generation aluminum coagulant called PAX 18 was implemented to restore Długie Lake. The treatment was carried out in three stages: in spring 2001, autumn 2002, and autumn 2003. Twenty tons of the coagulant was dosed each time. This corresponded to $6.79 \mathrm{~g} \mathrm{Al} \mathrm{m}^{-2}$ of the bottom surface (Gawrońska and Brzozowska 2002). The coagulant was dosed from 
Table 1 Selected morphometric data bowls lake (by IFI 1958)

Indicator
Surface water table
Maximum depth
Average depth
Relative depth
Depth index
Water volume
Maximum length
Maximum width
Elongation
Average width
Length of shoreline
Shoreline development

Surface
Water volume
Max. depth
Mictic type

\begin{tabular}{|c|c|}
\hline \multicolumn{2}{|l|}{ Value } \\
\hline \multicolumn{2}{|l|}{$26.8 \mathrm{ha}$} \\
\hline \multicolumn{2}{|l|}{$17.3 \mathrm{~m}$} \\
\hline \multicolumn{2}{|l|}{$5.3 \mathrm{~m}$} \\
\hline \multicolumn{2}{|l|}{0.0334} \\
\hline \multicolumn{2}{|l|}{0.3} \\
\hline \multicolumn{2}{|l|}{$1,414,800 \mathrm{~m}^{3}$} \\
\hline \multicolumn{2}{|l|}{$1670 \mathrm{~m}$} \\
\hline \multicolumn{2}{|l|}{$240 \mathrm{~m}$} \\
\hline \multicolumn{2}{|l|}{6.9} \\
\hline \multicolumn{2}{|l|}{$160.4 \mathrm{~m}$} \\
\hline \multicolumn{2}{|l|}{$4080 \mathrm{~m}$} \\
\hline \multicolumn{2}{|l|}{2.23} \\
\hline Central part & Northern basin \\
\hline 13.4 ha & 11.1 ha \\
\hline $947,916 \mathrm{~m}^{3}$ & $424,440 \mathrm{~m}^{3}$ \\
\hline 17.3 & $5.0 \mathrm{~m}$ \\
\hline Dimictic & Dimictic \\
\hline
\end{tabular}

barrels on boats and distributed over the entire surface of the lake through perforated tubes.

Both restoration methods were developed and implemented by the Department of Water Protection Engineering, University of Warmia and Mazury in Olsztyn.

\subsection{Research Methods}

\subsubsection{Chemical Analysis of Water}

Analysis of the chosen water parameters (total phosphorus, total nitrogen, chlorophyll a, $\mathrm{BOD}_{5}$ ) was performed in samples taken with a Ruttner sampler from the central, deepest part of Lake Dhugie $(1 \mathrm{~m}$ below the water mirror and $16 \mathrm{~m}^{-1} \mathrm{~m}$ above the bottom) (16 samples in 1 year, every sample in triplicate). The water samples for analysis were taken monthly from April to November 1972 (during the inflow of domestic sewage), from April to November 1975 (after limiting the amount of domestic sewage), from April to November 1984 (after cutting off the inflow of domestic sewage), from April to November 1987, 1998, 2000 (during artificial aeration), from April to November 2001, 2003 (during phosphorus inactivation), from April to November 2011, 2013 (the control years after restoration), and from April to November 2017 (after cutting off the inflow of storm sewage). The samples were analyzed immediately after their delivery to the laboratory, and therefore, the preservation of samples was unnecessary. Chemical analyses of water were performed in accordance with the guidelines given in Standard methods (1999). The water properties selected for analyses were TN (the sum of TKN determined with the Kjeldahl method, nitrite nitrates), TP (analyzed spectrophotometrically with the molybdenum blue method after preliminary mineralization), $\mathrm{BOD}_{5}$ (by incubation at $20{ }^{\circ} \mathrm{C}$ ), chlorophyll a (by spectrophotometric method after filtration using a Whatman $\mathrm{GF} / \mathrm{C}$ filter), and water transparency (with the Secchi disk visibility method).

\subsubsection{Statistical Methods}

The results were statistically analyzed (one-way ANOVA, $p=0.05$, Tukey's HSD) using Statistica 9.0 software package (Statsoft Inc. 2016). An alternative hypothesis tested was the presence of significant differences in mean annual values of nutrients between the control year (1972) and subsequent stages of lake protection and recultivation (1975, 1984 - after limiting and after cutting off the inflow of domestic sewage; 1987, 1998, 2000-during artificial aeration; 2001, 2002, 2003 - during phosphorus inactivation) and 2011, 2013 (post-experimental years), and 2017 (post- 
Table 2 Results of one-way ANOVA analyses (with Tukey HSD) for investigated variables in Długie Lake $(n=656)$

\begin{tabular}{llll}
\hline Variable & F value & $p$ value & $\begin{array}{l}\text { Years which different significantly from 1972 (during inflow } \\
\text { of sewage) }\end{array}$ \\
\hline TP-surface water & 14.7290 & $<0.001$ & $1984,1987,1998,2000,2001,2003,2011,2013,2017$ \\
TP-near bottom water & 204.7034 & $<0.001$ & $1984,1987,1998,2000,2001,2003,2011,2013,2017$ \\
TN-surface water & 52.5678 & $<0.001$ & $1984,1987,1998,2000,2001,2003,2011,2013,2017$ \\
TN-near bottom water & 51.4598 & $<0.001$ & $1984,1987,1998,2000,2001,2003,2011,2013,2017$ \\
BOD $_{5}$-surface water & 6.0232 & $<0.001$ & $1984,1987,1998,2000,2001,2003,2011,2013,2017$ \\
BOD $_{5}$-near bottom water & 51.3196 & $<0.001$ & $1984,1987,1998,2000,2001,2003,2011,2013,2017$ \\
Chlorophyll a & 6.7018 & $<0.001$ & $1984,1987,1998,2000,2001,2003,2011,2013,2017$ \\
Visibility of Secchi disk & 20.6867 & $<0.001$ & $1984,1987,2011,2013,2017$ \\
\hline
\end{tabular}

experimental year after cutting off the inflow of storm sewage; actual trophic state of the lake).

\section{Results}

The statistical analysis revealed significant differences between 1972 (during inflow of domestic and storm sewage), 1987-2000 (during artificial aeration), 2001-
2003 (during phosphorus inactivation), and 2011-2017 (after recultivation and cutting off storm sewage inflow) in the contents of nutrients, organic matter, chlorophyll $\mathrm{a}$, and water transparency in the entire volume of the lake (Table 2).

In 1972, with the inflow of sewage, the average concentration of TP $( \pm \mathrm{SD})$ in the surface water layer was $1.65 \pm 1.37 \mathrm{mg} \mathrm{P} \mathrm{L}^{-1}$ and in the near-bottom water layer was $6.04 \pm 1.98 \mathrm{mg} \mathrm{P} \mathrm{L}^{-1}$ (Fig. 2). After limiting

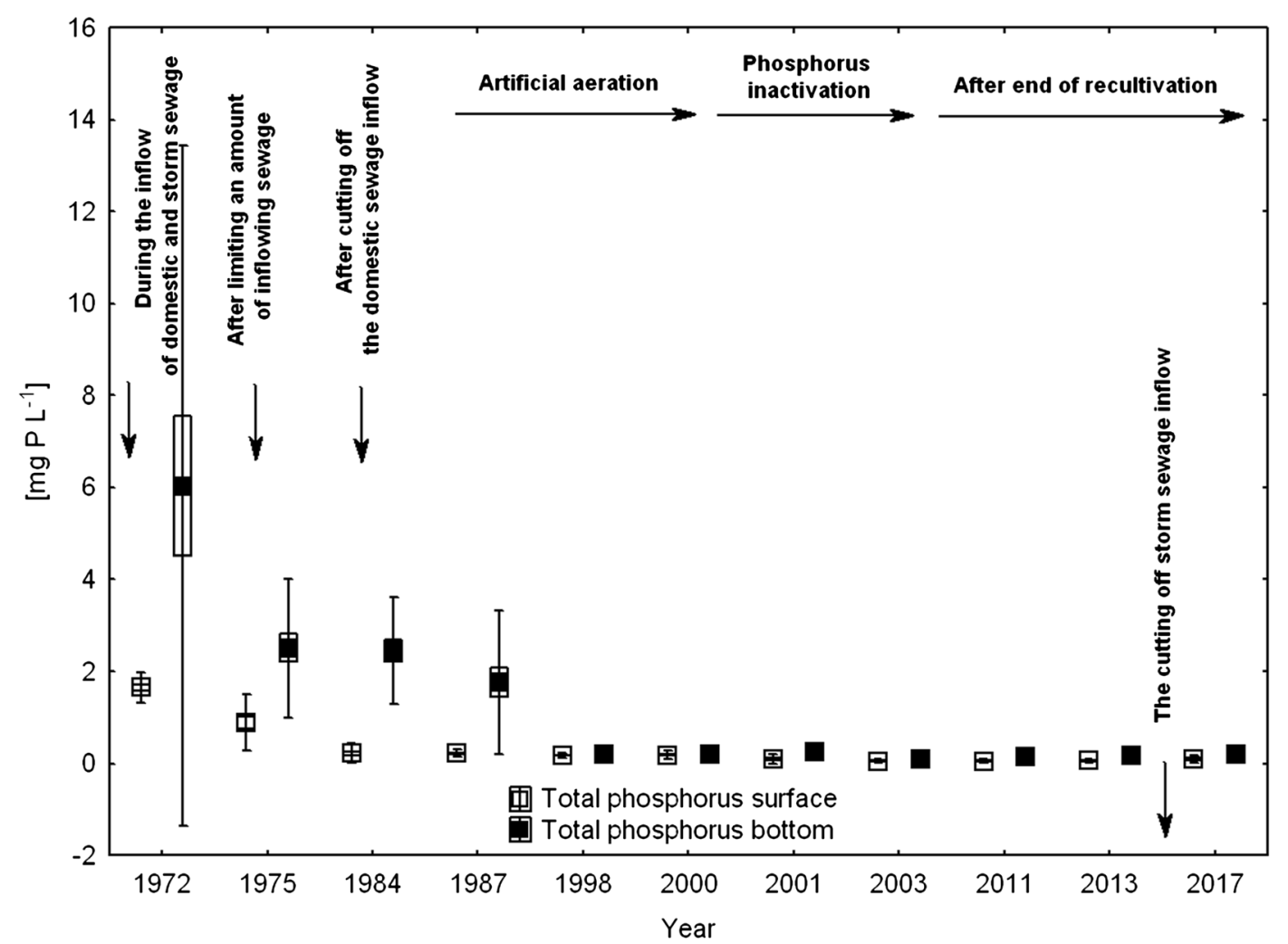

Fig. 2 Average annual values of total phosphorus ( \pm SEM and $2 * \mathrm{SD})$ in the water of Dhugie Lake $\left(\mathrm{mg} \mathrm{P} \mathrm{L}^{-1}\right)$ 
the amount of inflowing sewage, the average concentration of TP decreased to $0.89 \pm 0.27 \mathrm{mg} \mathrm{P} \mathrm{L}^{-1}$ in the surface water layer and to $2.51 \pm 1.00 \mathrm{mg} \mathrm{P} \mathrm{L}^{-1}$ in the near-bottom water layer (Fig. 2). Before recultivation and after cutting off the inflow of domestic sewage (1984), the mean quantity of TP in the surface water layer was $0.24 \pm$ $0.02 \mathrm{mg} \mathrm{P} \mathrm{L}^{-1}$ and in the near bottom layer was $2.45 \pm$ $1.28 \mathrm{mg} \mathrm{P} \mathrm{L}^{-1}$ (Fig. 2). During artificial aeration, the mean TP values decreased to ca. $0.18 \pm 0.13 \mathrm{mg} \mathrm{P} \mathrm{L}^{-1}$ in the upper water layer and to $0.20 \pm 0.17 \mathrm{mg} \mathrm{P} \mathrm{L}^{-1}$ near the bottom. The P inactivation method (2003) caused a further reduction of total phosphorus amounts to $0.06 \pm 0.02 \mathrm{mg} \mathrm{P}$ $\mathrm{L}^{-1}$ at the surface and $0.09 \pm 0.02 \mathrm{mg} \mathrm{P} \mathrm{L}^{-1}$ in the nearbottom water (Fig. 2). In 2017, 14 years after the end of recultivation and after cutting off the inflow of storm wastewater, the average TP concentration increased to $0.09 \pm 0.01 \mathrm{mg} \mathrm{P} \mathrm{L}^{-1}$ at the surface and to 0.21 $\pm 0.15 \mathrm{mg} \mathrm{P} \mathrm{L}^{-1}$ near the bottom (Fig. 2).

In 1972, during the inflow of sewage, the average concentration of $\mathrm{TN}( \pm \mathrm{SD})$ in the surface water layer was $9.05 \pm 4.78 \mathrm{mg} \mathrm{N} \mathrm{L}^{-1}$ and in the near-bottom water layer was $19.53 \pm 12.37 \mathrm{mg} \mathrm{N} \mathrm{L}^{-1}$ (Fig. 3). After limiting the amount of inflowing sewage, the average concentration of TN in the surface water layer decreased to $3.19 \pm 1.32 \mathrm{mg} \mathrm{N} \mathrm{L}^{-1}$, and in the near-bottom water layer, it decreased to $12.67 \pm 4.68 \mathrm{mg} \mathrm{N} \mathrm{L}^{-1}$ (Fig. 3). In 1984 , before the restoration and after limiting of sewage inflow, the average amount of TN in the surface layers of the lake water was $3.21 \pm 3.74 \mathrm{mg} \mathrm{N} \mathrm{L}^{-1}$, and in the near bottom water layers, it was $20.48 \pm 16.13 \mathrm{mg} \mathrm{N} \mathrm{L}^{-1}$ (Fig. 3). Artificial aeration caused a radical decrease in TN concentration (in 2000, mean values of 1.5 $1.7 \mathrm{mg} \mathrm{L}^{-1}$ ), especially in the lower layers of the water (Fig. 3). During phosphorus inactivation, in the upper water layer, the average amount of TP was similar to the values reported during aeration, and the nitrogen content near the bottom doubled in comparison to the levels recorded during artificial aeration (mean concentration ca. $2.8 \mathrm{mg} \mathrm{N} \mathrm{L}^{-1}$ ) (Fig. 3). Fourteen years after the restoration, and after cutting off the inflow of storm sewage, a slight decrease in the surface concentration of TN was noted, while the value remained at approximately $1.50 \mathrm{mg} \mathrm{N} \mathrm{L}^{-1}$ near the bottom (Fig. 3).

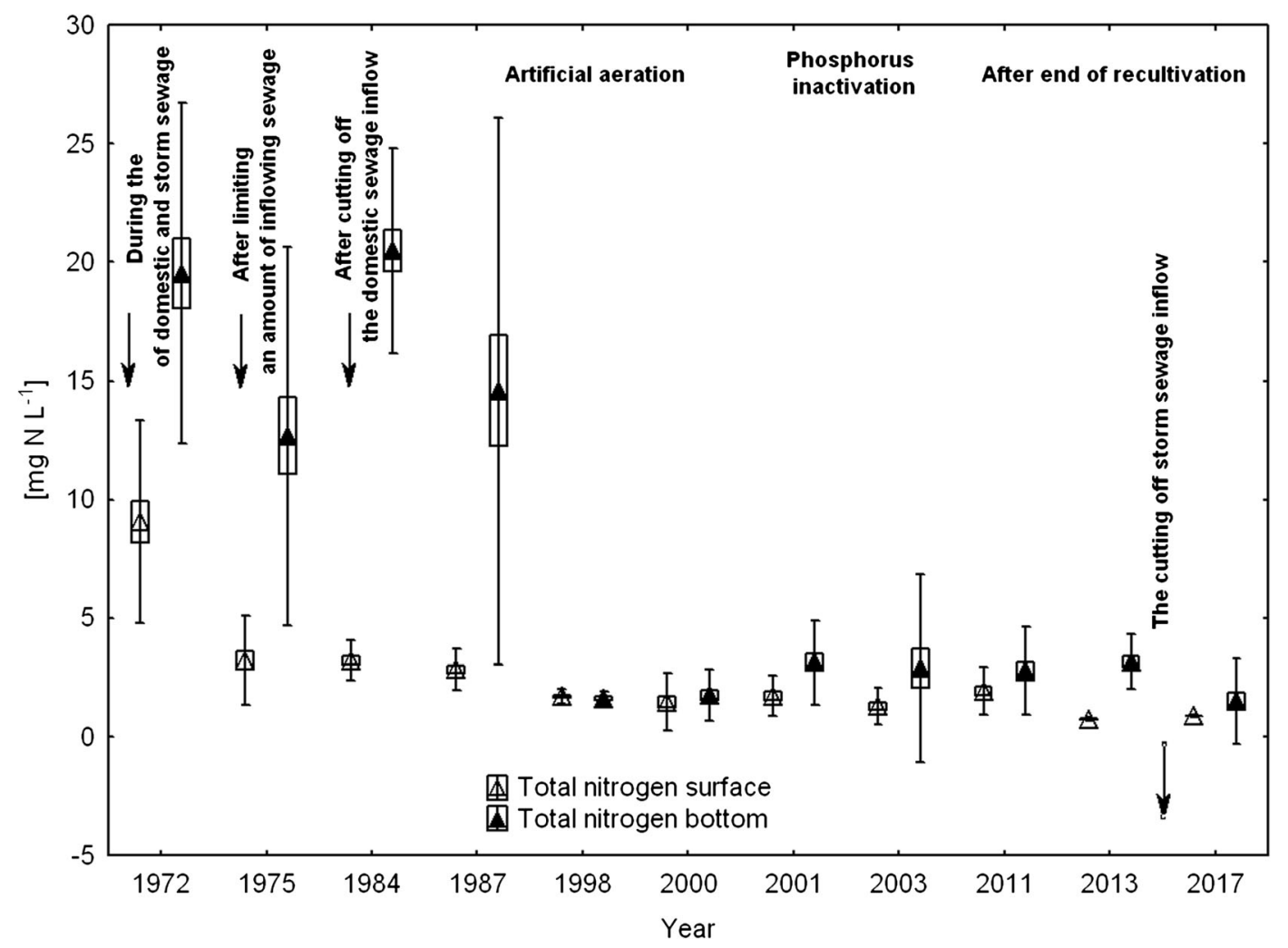

Fig. 3 Average annual values of total nitrogen $( \pm \mathrm{SEM}$ and $2 * \mathrm{SD})$ in the water of Długie Lake $\left(\mathrm{mg} \mathrm{N} \mathrm{L}^{-1}\right)$ 


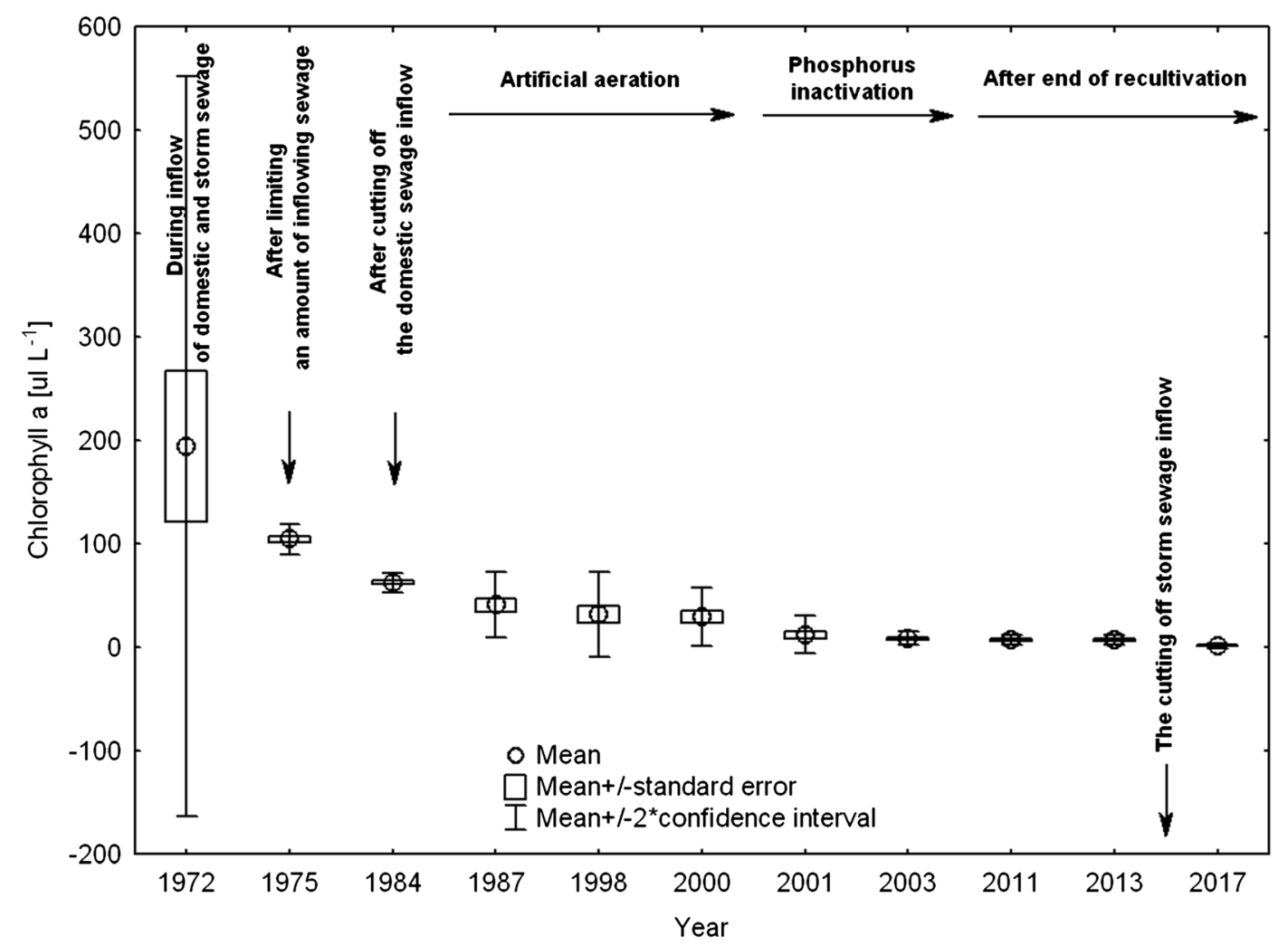

Fig. 4 Average annual values of chlorophyll a ( \pm SEM and $2 * \mathrm{SD})$ in the water of Długie Lake $\left(\mu g \mathrm{~L}^{-1}\right)$

The average amount of chlorophyll a in 1972 (during inflow of sewage) $( \pm \mathrm{SD})$ in the water of Długie Lake was $193.97 \pm 163.91 \mu \mathrm{g} \mathrm{L}^{-1}$ (Fig. 4). In 1976, after limiting the amount of incoming sewage, the mean value of chlorophyll a decreased to $104.47 \pm$ $89.49 \mu \mathrm{g} \mathrm{L}^{-1}$ (Fig. 4). The average amount of chlorophyll a in water in 1984, after cutting off the inflow of sewage, was $62.9 \pm 53.54 \mu \mathrm{g} \mathrm{L}^{-1}$. The beginning of artificial aeration with thermal destratification caused a marked decline in the concentration of chlorophyll a in the lake (Fig. 4). In the last year of the lake's aeration (2000), the average chlorophyll a concentration at the surface was $29.38 \pm 14.16 \mu \mathrm{g} \mathrm{L}^{-1}$ (Fig. 4). In the years with phosphorus inactivation, the average amount of chlorophyll a ranged between 8.78 and $12.23 \mu \mathrm{g} \mathrm{L}^{-1}$ (Fig. 4). In the post-experimental years $(2011,2013$, 2017), a further decrease in the chlorophyll a content to mean values in the range of 7.38-1.68 $\mu \mathrm{g} \mathrm{L}^{-1}$ (Fig. 4) was noted.

In 1972, during the inflow of sewage, the average value of the Secchi disk visibility was $2.1 \mathrm{~m}$ (Fig. 5). After limiting the amount of inflowing sewage, the average value of transparency decreased to $1.5 \mathrm{~m}$.
Before the restoration and after cutting off the inflow of domestic sewage (1984), the average value of water transparency was $0.4 \mathrm{~m}$ (Fig. 5). Artificial aeration induced an almost threefold increase in this parameter (Fig. 5). During aeration, the mean water transparency oscillated at approximately $1 \mathrm{~m}$. The phosphorus inactivation method caused further improvement of water transparency, the average level of which was $2 \mathrm{~m}$ in the last year of the treatment (Fig. 5). In 2011 and 2013 (8 and 10 years after the restoration procedures, respectively), the mean value of this parameter reached $3 \mathrm{~m}$ (Fig. 5). In 2017 , the average value of the Secchi disk visibility increased to $5.3 \mathrm{~m}$ (Fig. 5).

In 1972, the average value of $\mathrm{BOD}_{5}( \pm \mathrm{SD})$ in the surface layer of lake water was $7.9 \pm 2.8 \mathrm{mg} \mathrm{O}_{2} \mathrm{~L}^{-1}$ and in the near-bottom layer was $12.60 \pm 5.70 \mathrm{mg} \mathrm{O}_{2} \mathrm{~L}^{-1}$ (Fig. 6). Similar values were noted in 1976. In 1984, before the restoration and after cutting off the inflow of domestic sewage, the mean value of $\mathrm{BOD}_{5}$ in the surface layer of lake water was $6.90 \pm 2.80 \mathrm{mg} \mathrm{O}_{2} \mathrm{~L}^{-1}$, but in over bottom layer, it was $68.20 \pm 51.00 \mathrm{mg} \mathrm{O}_{2} \mathrm{~L}^{-1}$ (Fig. 6). The implementation of the artificial aeration procedure in 1987 resulted in increasing $\mathrm{BOD}_{5}$ values, 


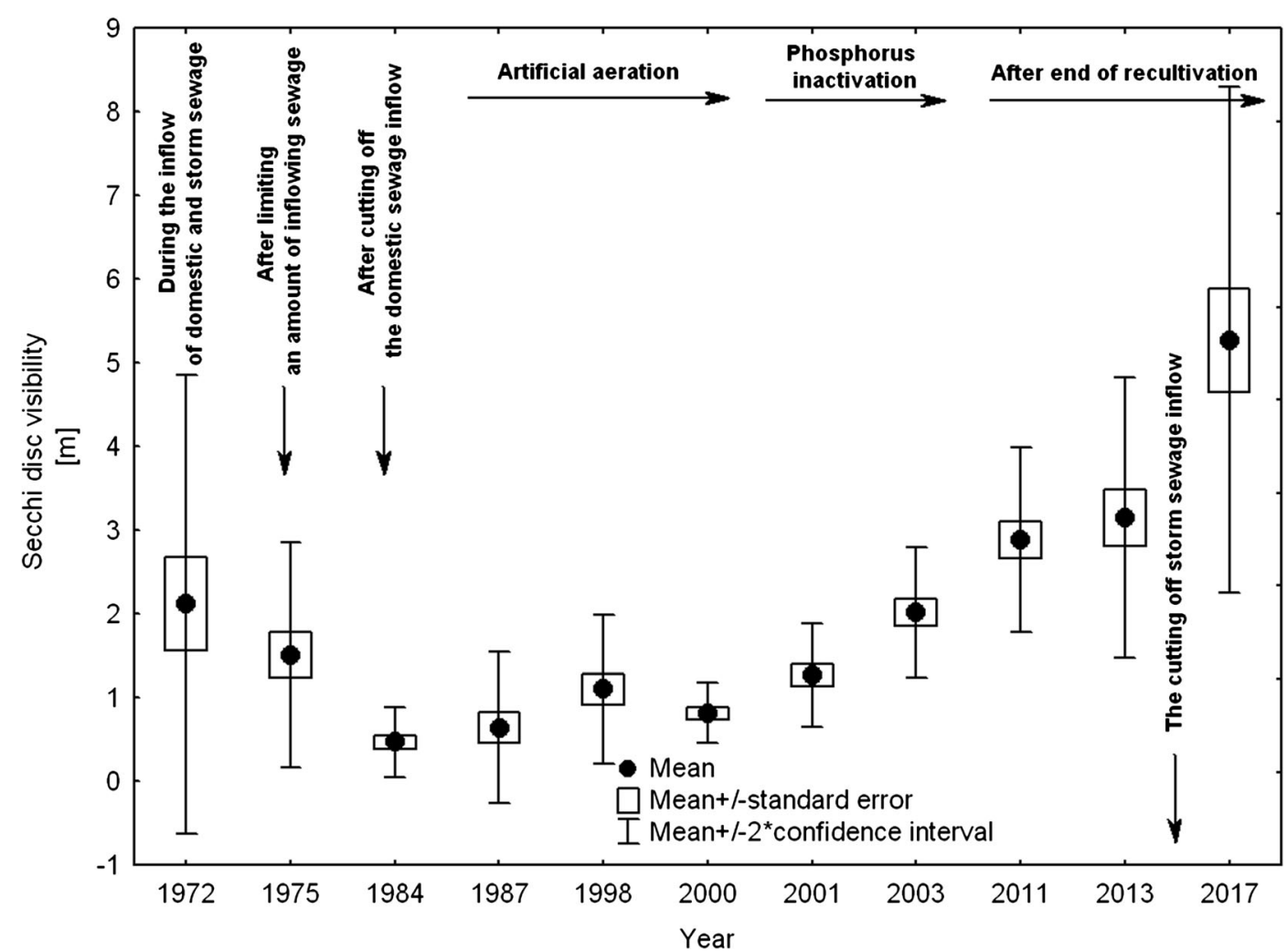

Fig. 5 Average annual water transparency ( \pm SEM and $2 * S D)$ in Długie Lake (m)

especially in the surface water layer (Fig. 6). In the last year of artificial mixing, the average values of $\mathrm{BOD}_{5}$ decreased and oscillated at approximately $4.70 \pm$ $0.50 \mathrm{mg} \mathrm{O} \mathrm{L}^{-1}$ in the surface layer and approximately $3.20 \pm 0.10$ in the near-bottom water layer (Fig. 6). When the phosphorus inactivation treatment was carried out in the lake (2001-2003), the average values of $\mathrm{BOD}_{5}$ in the upper water layer ranged from 2.20 to $4.30 \mathrm{mg} \mathrm{O}_{2} \mathrm{~L}^{-1}$ and in the near-bottom layer from 1.70 to $2.20 \mathrm{mg} \mathrm{O}_{2}$ $\mathrm{L}^{-1}$ (Fig. 6). In the post-experimental year (2017), the mean value of $\mathrm{BOD}_{5}$ in the surface water layer was found to be $1.00 \pm 0.30$ and in the near-bottom layer was $1.30 \pm 0.60 \mathrm{mg} \mathrm{O}_{2} \mathrm{~L}^{-1}$ (Fig. 6).

\section{Discussion}

Considering the statistical analysis of the obtained experimental results (BACI design) (Smith 2002), BA type analysis was used, i.e., before treatment-after treatment. The point of reference in our considerations was the average value of the analyzed parameters recorded in the lake before any protective and recultivation activities (such as limiting the amount of flowing sewage, total cut off of sewage inflow, recultivation by artificial aerationtwo stages, phosphorus inactivation, cutting off the inflow of storm sewage).

The initial information about the environmental conditions in the water of Długie Lake was provided by Olszewski and Paschalski (1959). The authors noted a very high trophic status based on the studies of thermaloxygen settings made at the end of the summer of 1956, where the unfavorable distribution of oxygen in the water column was indicated. In the epilimnion layer up to $3 \mathrm{~m}$ in depth, water oxygenation was found to be high (115\%), but deeper into the lake, there was a rapid decrease in the amount of oxygen dissolved in water, up to $53 \%$ at $4 \mathrm{~m}$ and $0 \%$ at $5 \mathrm{~m}$. The hypolimnion water contained hydrogen sulfides. This situation was caused by the inflow of sewage discharged through collectors on the eastern and western shores of the lake. From the mid-1950s, via an emergency overflow, untreated domestic sewage discharged to the southern bay of Długie Lake (approximately 350-400 $\mathrm{m}^{3}$ day $^{-1}$ ). In a short time, this led to complete degradation of the reservoir and a change of the trophic state from eutrophic to 


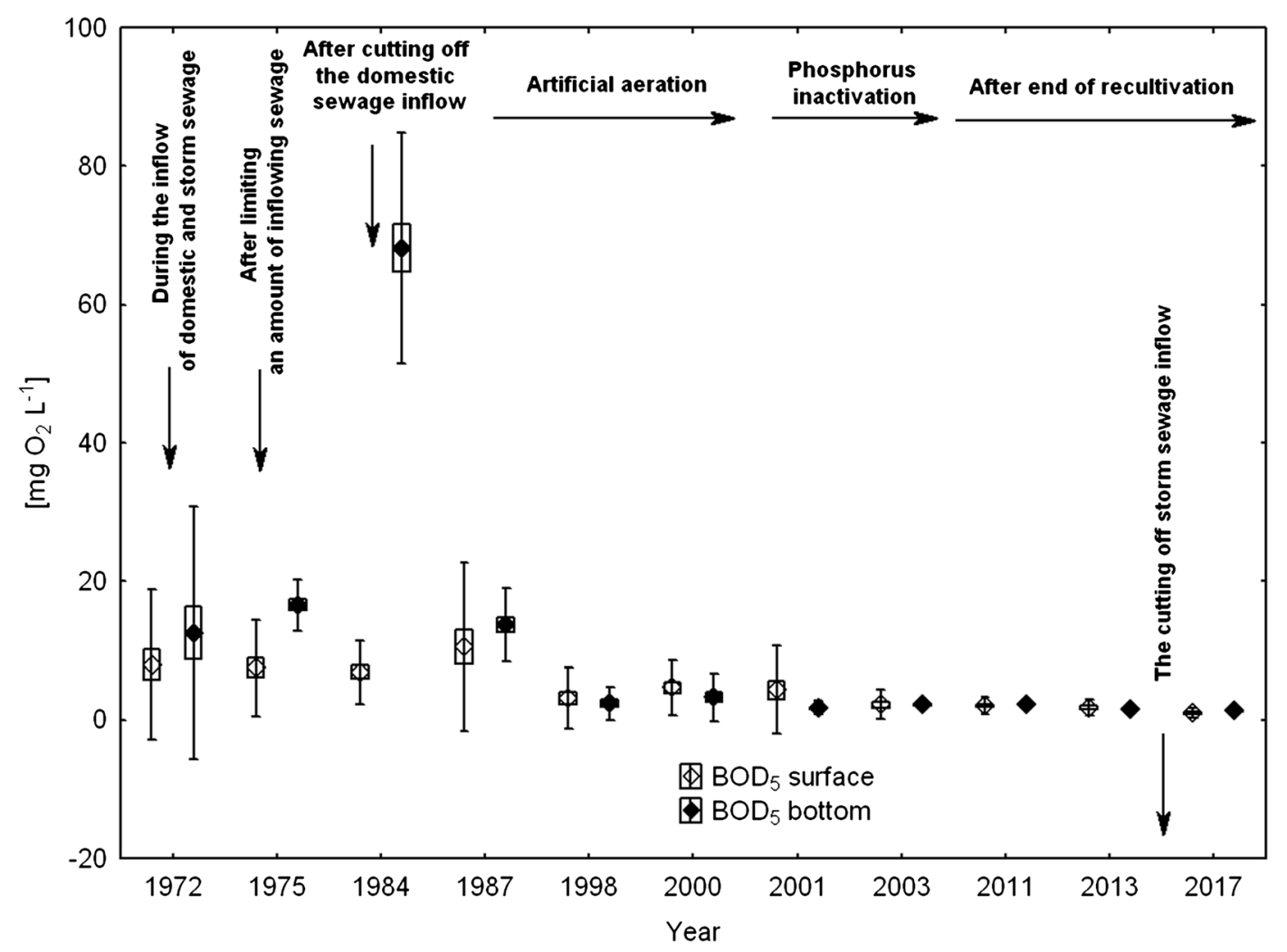

Fig. 6 Average annual $\mathrm{BOD}_{5}( \pm \mathrm{SEM}$ and $2 * \mathrm{SD})$ in Długie Lake $\left(\mathrm{mg} \mathrm{O}_{2} \mathrm{~L}^{-1}\right)$

saprotroph (Gawrońska et al. 2005). Research on the lake carried out in the 1970s (during the period of the highest pollution) showed that the water of Długie Lake contained extremely high concentrations of phosphorus and nitrogen, similar to those found in diluted sewage (Mientki et al. 1979). In the surface water layer, the TP content was $2.0 \mathrm{mg} \mathrm{P} \mathrm{L}^{-1}$ and nitrogen content was $12.5 \mathrm{mg} \mathrm{N} \mathrm{L}^{-1}$. In the near-bottom water layer, the determined values were as follows: over $12.0 \mathrm{mg} P$ $\mathrm{L}^{-1}$ of TP and over $31.0 \mathrm{mg} \mathrm{N} \mathrm{L}^{-1}$ of TN. Such high concentrations of nutrients favored primary production in the lake. However, Mucha (1979) found disturbances in biomass production, which were confirmed by large seasonal variations of chlorophyll a from $1.09 \mathrm{\mu g} \mathrm{L}^{-1}$ in June 1972 to $514.30 \mu \mathrm{g} \mathrm{L}^{-1}$ in August 1972. Phytoplankton in Długie Lake was exceptionally poorly diversified in the number of species, with an evident predominance of cyanobacteria (Mucha and Rybak 1979). The poor species composition of zooplankton, bottom macrofauna (Sikorowa 1979), and the intensive growth of bacterioplankton-106-108 CFU in $1 \mathrm{~cm}^{3}$ of water (Zmysłowska and Sobierajska 1980)_also evidenced strong pollution of the lake. The environmental conditions prevailing at that time in Długie Lake indicated the need to take protective measures not only to prevent further degradation of the lake but also to allow for its renewal.

According to Reynolds (2003), one of the most effective ways to reduce lake trophic level is by cutting off the inflow of nutrients from the catchment. This is a first and basic protection procedure, preceding a possible decision on the application of restoration activities. The response of lakes to the reduction of the inflow of pollutants can be variedfrom total renewal, to a slight improvement of water quality to the absence of any changes. In 1973, there was a reduction in the amount of domestic sewage discharged into the lake, and sewage discharge to the lake was completely terminated in 1976. Gawrońska's research (1984), carried out after starting the protective measures in the catchment, showed that the changes caused by the cessation of the sewage inflow were small and only quantitative. Suspension of sewage discharge was not enough to restore this lake, but it was undoubtedly necessary before proceeding with its reclamation. 
The most frequent goal of the lake restoration method is to improve the environmental condition by limiting the amount of nutrients. In lakes with an advanced trophic level and oxygen depletion in the near-bottom zone, sediments act as a significant phosphorus source and become the cause of secondary pollution (Selig and Schlungbaum 2003). The substances stored in sediments may have a harmful impact on lake water quality for a long time.

Studies have shown that the use of artificial aeration did not cause significant changes in the total phosphorus content in the surface water layer. However, a very large reduction in the phosphorus amount was observed in the near-bottom water. In 1984, before the restoration, the TP concentrations ranged from 2.5 to $3.5 \mathrm{mg} \mathrm{P} \mathrm{L}^{-1}$. During the first stage of aeration, TP decreased to approximately $0.5 \mathrm{mg} \mathrm{P} \mathrm{L}^{-1}$, and from 1998 to 2000 , it never exceeded $0.25 \mathrm{mg} \mathrm{P} \mathrm{L}^{-1}$. The TP decrease in the lake during aeration was mainly due to a decrease in the concentration of mineral phosphorus. In the water normally occupied by the hypolimnion, a decrease of phosphates was reported since the beginning of the restoration procedure. It was slight in the first restoration year, but in the next few years, especially in the second aeration stage, the phosphate concentration was approximately 10 -fold lower than before the restoration (Grochowska and Gawrońska 2004). The reason for this might be the translocation of phosphates into the surface layer and their distribution in the whole water volume. In addition, due to the near bottom water oxygenation improvement, the release of mineral phosphorus from sediments was inhibited, and consequently, the mineral $\mathrm{P}$ concentration decreased in the near-bottom water as well as in the whole lake. This assumption was also confirmed by the results obtained by Keizer and Sinke (1992), who found that the improvement of near-bottom water oxygenation can result in a decrease of diffusive $P$ released in the sediment-water interface.

Many authors (Seitzinger et al. 2006; Hamersly et al. 2009) maintain that the nitrogen decrease in water is caused by increased sedimentation of organic matter and its deposition in the sediments or by ammonification and denitrification of organic compounds to free nitrogen. It should be emphasized that the main path of free nitrogen is denitrification after prior nitrification (Puchalski et al. 1995). However, another possibility can occur in the bottom sediment of lakes. In the case of a lack of nitrates because of ammonia depletion, ammonia can be transformed into $\mathrm{N}_{2}$ via the anammox pathway (Sutyła et al. 2009). Microorganisms play a main role in nitrogen transformation, whose activity is dependent on many environmental factors. Ammonification may occur under both aerobic and anaerobic conditions under a wide $\mathrm{pH}$ and temperature range, and the intensity of this process depends on the number of the respective physiological groups of bacteria present (Niewolak and Potocka 1989). An improvement in oxygen conditions in the deeper part of the lake by artificial aeration resulted in a rapid decrease in ammonia nitrogen content by its oxidation to nitrate nitrogen. The processes of ammonia oxidation (nitrification) were favored by elevated temperatures, which were achieved by continuous water mixing and heating via contact with the atmosphere. The effect of these changes was a clear increase in the amount of nitrates in the lake (Grochowska and Brzozowska 2015). This form of nitrogen in the surface layer of the lake water can be consumed by intensively developing phytoplankton (Czaplicka-Kotas et al. 2012), and in the bottom part of lake water, it can be reduced to gaseous nitrogen (denitrification). According to Helmroos et al. (2012) and Liu et al. (2018), denitrification is the main process leading to the loss of nitrogen from aquatic ecosystems, and it occurs with the participation of heterotrophic or relatively heterotrophic bacteria, which are active at a wide temperature range of $5-35^{\circ} \mathrm{C}$. The water $\mathrm{pH}$ also influences the intensity of this phenomenon; the optimum is between $\mathrm{pH} 7.0$ and $\mathrm{pH}$ 8.2. However, the most important factor is proper oxygen conditions (Hunting and Van der Geest 2011). In Długie Lake during artificial aeration, denitrification may have been the main process in sediment. Factors that were favorable to denitrification processes in the sediment were high organic matter contents, lower $\mathrm{pH}$, and anaerobic conditions inside of the sediment (Brzozowska and Gawrońska 2009). The artificial aeration with thermal destratification caused a distinct change in the content of nitrogen compounds in Długie Lake. The total nitrogen amount decreased ten times (Fig. 3).

When further improvement of water quality using artificial aeration was no longer possible (low sorption capacity of the sediments, the lack of iron and manganese in water), the phosphorus inactivation method was used. This method is based on phosphorus precipitation from the water column and its immobilization in the bottom sediment. After the lake's artificial aeration was terminated, the waters returned to the previous thermal 
and oxygen arrangement (with hypoxia in the hypolimnion); therefore, aluminum coagulant PAX 18 was used. Gumińska (2011) stated that aluminum forms strong bonds with phosphorus, durable even in anaerobic conditions, and has low oxidation-reduction potential.

After the introduction of the first coagulant dose, almost complete precipitation of phosphate from the upper water was observed. In the hypolimnion, the decrease in the phosphate amount was slight, but clear inhibition of $\mathrm{P}$ release from the sediment was observed. After application of the next PAX 18 dose, the presence of mineral phosphorus was not detected in the surface layer, while in the near-bottom zone, its concentration did not exceed $0.039 \mathrm{mg} \mathrm{P} \mathrm{L}^{-1}$ (Grochowska et al. 2013). This was an effect of the min $P$ release radical blockage from sediment, and it was indicated by the min $\mathrm{P}$ decrease in the interstitial water (Gawrońska and Lossow 2003; Brzozowska et al. 2012).

The phosphorus inactivation method helped to radically reduce the total amount of phosphorus in Długie Lake. In 2003, total phosphorus concentrations ranged from 0.054 to $0.144 \mathrm{mg} \mathrm{P} \mathrm{L}^{-1}$ (Fig. 2).

The phosphorus inactivation method does not substantially change the content of nitrogen compounds. It should be noted that the precipitation of phosphorus from the water column to the bottom sediment also resulted in a clear increase in the N/P ratio. This is a very important indicator in the determination of the dominance of certain species of algae (Helmroos et al. 2012). An increase in the N/P ratio to above 14 causes the disappearance of blue-green algae blooms and stimulates the growth of algae that are more desirable ecologically (Quan and Falkowski 2009; Pawlikowski et al. 2013). Before the restoration, the N/P ratio in the surface water layer ranged from 3 to 12; during the artificial aeration, it ranged from 8 to 23 , while during phosphorus inactivation and after the termination of the reclamation, it increased to a range of 20-78.

Even 10 years after the recultivation treatments were stopped, Dhugie Lake has good water quality, but a slight increase in the content of TP and TN was observed in the near-bottom zone. It should be noted that the lake is located at the lowest drainage basin point, and thus, it is

Table 3 Current TSI index value for Długie Lake

\begin{tabular}{ccccc}
\hline Trophic state index & TSI $_{\mathrm{TP}}$ & $\mathrm{TSI}_{\mathrm{TN}}$ & $\mathrm{TSI}_{\mathrm{SD}}$ & $\mathrm{TSI}_{\mathrm{Chl}}$ \\
& 64 & 52 & 38 & 39 \\
\hline
\end{tabular}

continuously loaded with natural substances from the catchment and with some inflow of storm sewage. However, in 2015 , the inflow of storm sewage was stopped.

The limitation of the inflow of pollutants to Długie Lake has resulted in a slight improvement of the environmental conditions in the lake. In the range given by Zdanowski (1982), considering the spring content of phosphorus in the lake, Długie Lake can be classified as a meso-eutrophic water body, having the 2 nd degree of a trophic state. In the trophic classification of Carlson (1977), the value of the TSI ${ }_{T P}$ indicator for the tested lake positions in Długie Lake was in the middle of the range established for eutrophic lakes (Table 3). Considering the trophic classification by Kratzer and Brezonik (1981) based on summer measurements of nitrogen concentrations, supplemented by the Carlson classification (1977), Długie Lake is located on the borderline of mesotrophy and eutrophy (Table 3).

One of the most important parameters reflecting the trophic status of water is Secchi disk visibility. According to Borowiak (2000), the amount of dissolved salts, the density of live and dead suspension, the color of water and, above all, the concentration of plankton determine the penetration of light rays. In 2017, the water transparency in Długie Lake ranged from 3.2 to $7.3 \mathrm{~m}$, and the average value in the growing season oscillated around approximately $5 \mathrm{~m}$. In the analyzed lake, the Secchi disc visibility range was largely regulated by the development of algae, which is confirmed by the high negative correlation $(r=0.84, p<0.05, n=$ 144 ) between visibility and chlorophyll a content, considered to be an indicator best expressing the volume of primary production. Our research in 2017 showed that the largest amount of chlorophyll a $\left(2.99 \mu \mathrm{g} \mathrm{L}^{-1}\right)$ recorded at the peak of summer stagnation coincided with the lowest water transparency-3.2 $\mathrm{m}$. According to the classification developed by Faraś-Ostrowska and Lange (1998), based on the Secchi disk visibility range obtained, the analyzed lake can be described as mesotrophic. Długie Lake was distinctly diverse in terms of biogenic parameters of the trophic status, such as $\mathrm{TSI}_{\mathrm{TP}}$ and TSI $_{\mathrm{TN}}$, according to Carlson (1977), and the indicators defining the primary production volume, i.e., $\mathrm{TSI}_{\mathrm{Chl}}$ and $\mathrm{TSI}_{\mathrm{SD}}$ (Table 3). The TSI $\mathrm{SD}_{\mathrm{S}}$ and $\mathrm{TSI}_{\mathrm{Chl}}$ values are within the range established for mesotrophic water bodies.

In its long history of degradation, protection, and recultivation treatments, Długie Lake has been observed to undergo a significant change in the production of organic matter, which has radically decreased. In some past 
years, the $\mathrm{BOD}_{5}$ achieved a mean value above $60 \mathrm{mg} \mathrm{O}$ $\mathrm{L}^{-1}$, and we now note an average value of $\mathrm{BOD}_{5}$ of ca. $1.1 \mathrm{mg} \mathrm{O}_{2} \mathrm{~L}^{-1}$. Currently, the lake is a mesotrophic water body, within which the processes of organic matter production and decomposition are sustainable.

\section{Conclusions}

The history of Długie Lake shows how inappropriate wastewater management can easily destroy a sensitive lake ecosystem and turn the lake's waters into diluted sewage. For twenty years, Długie Lake received raw domestic sewage, and for over 40 years, it has been treated to finally achieve good environmental conditions. The research into Długie Lake shows that to ensure success in the process of lake restoration, it is necessary to reduce, as much as possible, the inflow of pollutants from the catchment and to combine several complementary recultivation methods. Having satisfied these requirements, it only takes a few years for stable environmental conditions to be created, thus implicating a possibility of maintaining the positive impact of lake renewal efforts, as these positive effects have been stable for a period of at least 10 consecutive years.

Today, chemical parameters (nutrient concentrations) and especially indicators defining primary production (chlorophyll a and Secchi disk visibility) indicate the mesotrophic nature of Długie Lake water.

Dhugie Lake is the only reservoir in Poland, and one of the few in the world, that has been successfully recultivated, and positive effects have been achieved for almost 20 years.

Acknowledgements The authors wish to kindly thank Professor Helena Gawrońska for scientific consultations, Marzena Karpienia for making the laboratory analyses, Jolanta Idźkowska (English School) and Wayne Melgaard (Native Speaker) for language correction of manuscript.

Funding Information This study was funded from the statutory subject. Problem group No 38 UPB titled "Inland water ecosystems, its protection and restoration of lakes" Subject No 0806.0802: "Improvement of the water reservoirs protection and restoration methods".

Open Access This article is distributed under the terms of the Creative Commons Attribution 4.0 International License (http:// creativecommons.org/licenses/by/4.0/), which permits unrestricted use, distribution, and reproduction in any medium, provided you give appropriate credit to the original author(s) and the source, provide a link to the Creative Commons license, and indicate if changes were made.

\section{References}

Borowiak, D. (2000). Conditions of light field diversification in upper Radun Lake, Kashubian Lake District. IV limn. Conference on "natural and anthropogenic changes of lakes Olsztyn" (pp. 68-99).

Brzozowska, R., \& Gawrońska, H. (2005). Influence of a multiyear artificial aeration of a lake using destratification method on the sediment-water phosphorus exchange. Archive of Environmental Protection, 31(3), 71-88.

Brzozowska, R., \& Gawrońska, H. (2009). The influence of a long-term artificial aeration on the nitrogen compounds exchange between bottom sediments and water in Lake Dhugie. Oceanological and Hydrobiological Studies, 38(1), 113-119.

Brzozowska, R., Grochowska, J., \& Gawrońska, H. (2012). The role of bottom deposits in the long-term durability of Lake restoration effects - the case of a degraded urban lake (Długie lake, Poland). Libro de Resumenes del I Congreso Internacional de Ciencia y Tecnologia Ambiental, 1, 55.

Carlson, R. E. (1977). A trophic state index for lakes. Limnology and Oceanography, 22, 361-369.

Carpenter, S. R. (2008). Phosphorus control is critical to mitigating eutrophication. Proceedings of the National Academy of Science, 105, 11039-11040.

Colford, J. M., Jr., Wade, T. J., Schiff, K. C., Wright, C. C., Griffith, J. F., Sandhu, S. K., Burns, S., Sobsey, M., Lovelace, G., \& Weisberg, S. B. (2007). Water quality indicators and the risk of illness at beaches with nonpoint sources of fecal contamination. Epidemiology, 18(1), 27-35.

Czaplicka-Kotas, A., Ślusarczyk, Z., Pięta, M., \& Szostak, A. (2012). Analysis of dependencies between indicators of water quality in the lake Goczalkowice in the aspect of phytoplankton blooms. Environmental Protection, 34(1), 21-27.

Dunalska, J. A., \& Wiśniewski, G. (2016). Can we stop the degradation of lakes? Innovative approaches in lake restoration. Ecological Engineering, 95, 714-722. https://doi. org/10.1016/j.ecoleng.2016.07.017.

Dunalska, J. A., Grochowska, J., Wiśniewski, G., \& Napiórkowska-Krzebietke, A. (2015). Can we restore badly degraded urban lakes? Ecological Engineering, 82, 432-441.

Faraś-Ostrowska, B., \& Lange, W. (1998). Transparency of water as a measure of the severity of lake eutrophication. Degradation threats and lake protection. Limnology Research, 1, 181-191.

Fraterrigo, J. M., \& Downing, J. A. (2008). The influence of land use on lake nutrients varies with watershed transport capacity. Ecosystems. https://doi.org/10.1007/s10021-008-9176-6.

Gawrońska, H. (1984). Impact of limitation of sewage inflow on the physical and chemical conditions of the waters of Lake Dhugie in Olsztyn. Annual of Agriculture Sciences, 100(4), 27-52.

Gawrońska, H., \& Brzozowska, R. (2002). Influence of the PAX coagulant application on internal loading in Lake Długie. Limnological Review, 2, 111-119.

Gawrońska, H., \& Lossow, K. (2003). Possibilities of saprotrophic Lake recultivation exemplified by lake Dhugie in Olsztyn. Polish Journal of Environmental Studies, 12(3), 301-307.

Gawrońska, H., Lossow, K., \& Grochowska, J. (2005). Recultivation of Dlugie Lake in Olsztyn. Pub. Edycja (p. 52).

Grochowska, J., \& Brzozowska, R. (2015). Influence of different recultivation methods on the durability of nitrogen compounds changes in the waters of an urban lake. Water and Environment Journal, 29(2), 228-235. https://doi.org/10.1111/wej.12103. 
Grochowska, J., \& Gawrońska, H. (2004). Restoration effectiveness of a degraded lake using multi-year artificial aeration. Polish Journal of Environmental Studies, 13(6), 671-681.

Grochowska, J., \& Tandyrak, R. (2007). Nitrogen and phosphorus compounds in Lake Pluszne. Archives of Environmental Protection, 33(1), 59-66.

Grochowska, J., Karpienia, M., \& Tandyrak, R. (2011). Water chemistry and the protection concept of a lake subjected to agricultural pressure. Acta Scientiarum Polonorum Formatio Circumiectus, 10(3), 21-30.

Grochowska, J., Brzozowska, R., \& Łopata, M. (2013). Durability of phosphorus compounds changes in the water of urban lake after the application of two recultivation methods. Water Science and Technology, 68(1), 234-239.

Grochowska, J., Tandyrak, R., \& Wiśniewski, G. (2014). Longterm hydrochemical changes in a lake after the application of several protection measures in the catchment. Polish Journal of Natural Sciences, 29(3), 251-263.

Gumińska, J. (2011). Impact of transformation of aluminum forms on the effectiveness of water purification using polymerized coagulant. Environmental Protection, 33(2), 17-21.

Hamersly, M. R., Woebken, D., Boehrer, B., Schultze, M., Lavik, G., \& Kuypers, M. M. M. (2009). Water column an anammox and denitrification in a temperate permanently stratified Lake (lake Rassnitzer, Germany). Systematic and Applied Microbiology, 32, 571-582.

Helmroos, H., Hietanen, S., Niemistö, J., \& Horpilla, J. (2012). Sediment resuspension and denitrification affect the nitrogen to phosphorus ratio of shallow lake waters. Fundamental and Applied Limnology, 180(3), 193-205.

Hunting, E. R., \& Van der Geest, H. G. (2011). Predictability of bacterial activity and denitrification in aquatic sediments with continuous measurements of redox potential. International journal of Environmental Science and Technology, 8(3), 553-560.

Inoue, H., Tahoma, T., Yoshizaki, M., \& Agata, K. (2015). Detection of legionella species in environmental water by quantitative PCR method in combination with ethidium monoazide treatment. Biocontrol Science, 20(1), 71-74.

Istvánovics, V. (2009). Eutrophication of lakes and reservoirs. Encyclopedia of Inland Waters, 157-165.

Jeppesen, E., Søndergaard, M., Meerhoff, M., Lauridsen, T. L., \& Jensen, J. P. (2007). Shallow lake restoration by nutrient loading reduction - Some recent findings and challenges ahead. Hydrobiologia, 584, 239-252.

Jorgensen, S. E. (2001). Water quality. The impact of eutrophication. Lake and Reservoir, 3, 15-18.

Keizer, P., \& Sinke, A. J. C. (1992). Phosphorus in the sediment of the Loosdrecht lakes and its implications for lake restoration perspectives. Hydrobiologia, 233, 39-50.

Klapper, H. (2003). Technologies for lake restoration. Journal of Limnology, 62(1), 73-90.

Kratzer, C. R., \& Brezonik, P. L. (1981). A Carlson - type trophic state index for nitrogen in Florida lakes. Water Research Bulletin, 17, 713-715.

Liu, W., Yao, L., Jiang, X., Guo, L., Cheng, X., \& Liu, G. (2018). Sediment denitrification in Yangtze lakes is mainly influenced by environmental conditions but not biological communities. Science of the Total Environment, 616-617, 978987. https://doi.org/10.1016/j.scitotanev.2017.10.221.
Mientki, C., Drozd, H., \& Lossow, K. (1979). Phosphorus and nitrogen compounds in Dhugie Lake in Olsztyn. Science Notebooks Academy of Agriculture and Technology, 9, 31-45.

Miyagi, K., Hirai, I., \& Sano, K. (2016). Distribution of Aeromonas species in environmental water used in daily life in Okinawa prefecture, Japan. Environmental Health and Preventive Medicine, 21(5), 287-294.

Mucha, A. (1979). Primary production in Długie Lake in Olsztyn. Science Notebooks of Academy of Agriculture and Technology, 9, 63-72.

Mucha, A., \& Rybak, M. (1979). The chlorophyll content in the phytoplankton of Lake Długie. Science Notebooks of Academy of Agriculture and Technology, 9, 47-53.

Niewolak, S., \& Potocka, E. (1989). Seasonal changes in the number of active bacteria in the process of mineralization of nitrogen compounds in the water of the aerated lake. Acta Acad. Agricult. Tech. Olst. Protectio Aquarum et Piscatoria, 16, 201-209.

Olszewski, P., \& Paschalski, J. (1959). Preliminary limnological characterization of some lakes of the Masurian Lake District. Science Notebooks of Academy of Higher Agriculture School in Olsztyn, 4, 1-110.

Pawlikowski, P., Abramczyk, K., Szczepaniuk, A., \& Kozub, Ł. (2013). Nitrogen: Phosphorus ratio as the main ecological determinant of the differences in the species composition of brown-moss rich fens in North-Eastern Poland. Preslia, 85, 349-367.

Puchalski, W., Bis, B., \& Zalewski, M. (1995). Retention processes of nutrients in ecotones of rivers feeding dam reservoirs (pp. 155-176). Łódź: Environmental Monitoring Library.

Quan, T. M., \& Falkowski, P. G. (2009). Redox control of N:P ratios in aquatic ecosystems. Geobiology, 7, 124-139. https://doi.org/10.1111/j.1472-4669.2008.00182.x.

Reynolds, C. S. (2003). The development of perceptions of aquatic eutrophication and its control. Ecohydrology and Hydrobiology, 3(20), 149-163.

Seitzinger, S., Harrison, J. A., Böhlke, J. K., Bouwman, A. F., Lawrence, R., Peterson, B., Tobias, C., \& Van Drecht, G. (2006). Denitrification across landscapes and waterscape a synthesis. Ecological Applications, 16(6), 2064-2090.

Selig, U., \& Schlungbaum, G. (2003). Characterization and quantification of phosphorus release from profundal bottom sediments in two dimictic lakes during summer stratification. Journal of Limnology, 62(2), 151-162.

Sewell, A., Bouma, J., \& Van der Esch, S. (2016). Investigating the challenges and opportunities for scaling up ecosystem restoration. PBL Netherlands Environmental Assessment Agency, 2356, 1-78.

Sikorowa, A. (1979). Influence of domestic wastewater on the bottom macrofauna of Długie Lake in Olsztyn. Science Notebooks of Academy of Agriculture and Technology, 9, $71-83$.

Smith, E. P. (2002). BACI design. In A. H. El Shaarawi \& W. W. Piegorsch (Eds.), Encyclopedia of environmetrics (pp. 141148). Chichester: John Wiley \& Sons, Ltd.

StatSoft Inc. (2016). STATISTICA (data analysis software system), version 12.5. www.statsoft.com. Accessed 28 March 2019

Sutyła, M., Tomaszek, J. A., \& Masłoń, A. (2009). Anaerobic conversions of ammonium nitrogen in aquatic ecosystems. Environmental Protection Engineering, 35(2), 105-111. 
Wang, J., Zhang, K., \& Liang, B. (2012). Tracing urban sewage pollution in Chaohu Lake (China) using linear alkylbenzenes (LABs) as molecular marker. Science of the Total Environment, 414, 356-363.

Zdanowski, B. (1982). Variability of nitrogen and phosphorus contents and lake eutrophication. Polish Archive of Hydrobiology, 29(3-4), 541-597.
Zmysłowska, I., \& Sobierajska, M. (1980). Microbiological characteristics of Długie Lake in Olsztyn contaminated by domestic sewage. Science Notebooks of Academy of Agriculture and Technology, 10, 39-57.

Publisher's Note Springer Nature remains neutral with regard to jurisdictional claims in published maps and institutional affiliations. 